\title{
SEPT8 wt Allele
}

National Cancer Institute

\section{Source}

National Cancer Institute. SEPT8 wt Allele. NCI Thesaurus. Code C114431.

Human SEPT 8 wild-type allele is located in the vicinity of $5 q 31$ and is approximately $56 \mathrm{~kb}$ in length. This allele, which encodes septin-8 protein, is involved in cytoskeletal filament assembly. 